\title{
Social incentives for adherence to tuberculosis treatment
}

\author{
Incentivos sociais na adesão ao tratamento da tuberculose \\ Incentivos sociales en la adhesión al tratamiento de la tuberculosis
}

\section{Giovanna Mariah Orlandi \\ ORCID: 0000-0002-1451-7495 \\ Érica Gomes Pereira' \\ ORCID: 0000-0003-2873-4519}

Rosângela Elaine Minéo Biagolini"

ORCID: 0000-0003-2061-5611

Francisco Oscar de Siqueira França'

ORCID: 0000-0001-8510-7939

Maria Rita Bertolozzi'

ORCID: 0000-0002-5009-5285

'Universidade de São Paulo. São Paulo, São Paulo, Brazil.

"Universidade Nove de Julho. São Paulo, São Paulo, Brazil.

How to cite this article: Orlandi GM, Pereira EG, Biagolin REM, França FOS

Bertolozzi MR. Social incentives for adherence to tuberculosis treatment. Rev Bras Enferm. 2018;72(5):1182-8. doi: http://dx.doi.org/10.1590/0034-7167-2017-0654

Corresponding Author:

Giovanna Mariah Orlandi

E-mail: gmorlandi@usp.br

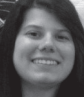

Submission: 10-24-2017 Approval: 03-28-2018

\begin{abstract}
Objective: To analyze the influence of social incentives for adherence to tuberculosis (TB) treatment. Method: Qualitative study, in which 26 primary health care professionals of São Paulo were interviewed in 2015. Their testimonies were submitted to the speech analysis technique. The theoretical reference was the social determination of the healthdisease process. Ethical procedures were observed. Results: TB is related to precarious living conditions. Incentives such as the basic food basket and transportation stipends are relevant for patients' adherence to treatment, as well as to the create bonds between the patient and the health team. Final considerations: The incentives strengthened adherence to TB treatment. However, interventions in the context of public measures must transcend the remedial dimension and be guided towards the transformation of the TB situation, which means supporting processes that modify living conditions. Descriptors: Tuberculosis; Medication Adherence; Public Policy; Nursing; Primary Health Care.
\end{abstract}

\section{RESUMO}

Objetivo: Analisar a influência de incentivos sociais na adesão ao tratamento da tuberculose (TB). Método: Estudo qualitativo, em que 26 profissionais da Atenção Primária à Saúde do município de São Paulo foram entrevistados em 2015, e seus depoimentos foram submetidos à técnica de análise de discurso. O referencial teórico foi a determinação social do processo saúde-doença. Os procedimentos éticos foram resguardados. Resultados: ATB está relacionada às condições precárias de vida, sendo que incentivos como a cesta básica e o vale-transporte são relevantes para a adesão do paciente ao tratamento, assim como para o vínculo entre o paciente e a equipe de saúde. Considerações finais: Os incentivos fortalecem a adesão ao tratamento da TB. Contudo, intervenções no âmbito de medidas públicas devem transcender a dimensão paliativa e orientarem-se para transformar a situação da TB, o que significa apoiar processos que modifiquem as condições de vida.

Descritores: Tuberculose; Adesão à Medicação; Política Pública; Enfermagem; Atenção Primária à Saúde.

\section{RESUMEN}

Objetivo: Analizar la influencia de los incentivos sociales en la adhesión al tratamiento de la tuberculosis (TB). Método: Estudio cualitativo, en el que 26 profesionales de la Atención Primaria a la Salud del municipio de São Paulo fueron entrevistados en 2015, y sus testimonios fueron sometidos a la técnica de análisis de discurso. El referencial teórico fue la determinación social del proceso salud-enfermedad. Se han resguardado los procedimientos éticos. Resultados: La TB se relaciona con las condiciones precarias de la vida, siendo que los incentivos como la canasta básica y la ayuda para el transporte son relevantes para la adhesión del paciente al tratamiento, así como para el vínculo entre el paciente y el equipo de salud. Consideraciones finales: Los incentivos fortalecen la adhesión al tratamiento de la TB. Sin embargo, las intervenciones en el marco de medidas públicas deben trascender la dimensión paliativa y orientarse para transformar la situación de la TB, lo que significa apoyar procesos que modifiquen las condiciones de vida.

Descriptores: Tuberculosis; Cumplimiento de la Medicación; Política Pública; Enfermería; Atención Primaria de Salud. 


\section{INTRODUCTION}

Tuberculosis (TB) is a disease of social nature, therefore, the way people live and work influences the illness ${ }^{(1)}$. In general, the disease is associated with the most vulnerable and marginalized social groups, which present compromised social conditions and low schooling, use alcohol and other drugs, live in urban areas, among other characteristics ${ }^{(2-3)}$. In 2015, the World Health Organization (WHO) estimated 10.4 million new cases of TB, 1.4 million deaths, and a $83 \%$ cure rate. In Brazil, in the same year, 84 thousand cases were estimated, 3.8 thousand deaths, and a $71 \%$ cure rate ${ }^{(4)}$. This rate is one of the elements of the monitoring strategy End TB, whose goal is to eliminate TB around the world. Both the world rate and the Brazilian rate are below the recommendation by WHO, which provides for a rate greater than $90 \%{ }^{(4)}$.

Precarious social situation, delay in searching for assistance, and lack of information about the illness and its treatment are some of the elements that contribute to the non-adherence to TB treatment ${ }^{(3)}$. Adherence is also related to the medication treatment itself (side effects, for example), immune deficiencies, access, and organization of the health service ${ }^{(2,5)}$. Treatment withdraw maintains the spread of the bacillus and enhances the risk of development of medication resistance ${ }^{(5-7)}$. Adherence, thus, cannot be reduced to a volitive act or to an exclusively individual act, but it is associated with other dimensions related to the production and social reproduction processes, i.e., related to social inclusion and living and working conditions.

In order to improve the indicators of the disease and to motivate adherence to the Directly Observed Treatment (DOT), the Ministry of Health recommends the provision of incentives to patients, such as snacks, food stipends and transportation stipends, since they present, in general, important vulnerabilities regarding their living conditions. Such incentives can contribute to the alleviation of the immediate needs of people affected by $\mathrm{TB}^{(8-9)}$. In addition to the mentioned incentives, Brazil counts with Social Protection (SP) measures not intended specifically to TB patients, but that help alleviate social vulnerabilities ${ }^{(10)}$. Among them are: disease aid for people who have contributed to the National Social Security Institute (INSS), the Bolsa Família program, the Continued Provision benefit, among others. It is considered that such measures support coping with the disease regarding not only the individuals affected by $T B$, but also the people who live with them ${ }^{(11-12)}$.

Even searching, in the Brazilian literature, for studies that discuss the central theme of this study ${ }^{(10,12)}$, the relevance of this article stand out due to the magnitude of TB, which is the leading cause of death among infectious diseases caused by a single agent, surpassing the deaths due to HIV infection ${ }^{(13)}$. Furthermore, Social Protection integrates the current strategy of WHO, End TB(4).

\section{OBJECTIVE}

To analyze the influence of social incentives for adherence to tuberculosis (TB) treatment, in the perspective of Primary Health Care professionals.

\section{METHOD}

\section{Ethical aspects}

All ethical procedures were observed. The research project was approved by the Research Ethics Committees of the School of Nursing, University of São Paulo and of the Health Department of the municipality of São Paulo.

\section{Theoretical-methodological framework}

We used the social determination of the health-disease process as theoretical-methodological framework, which considers structural, specific, and unique processes to understand the illness process. This means that society's organization mode, production mode, and social reproduction profiles (production and consumption) shall determine the health-disease profiles ${ }^{(14)}$. In addition, this framework is not limited to individual and biological processes, transcending to the interpretation of the health-disease process concerning its collective dimension ${ }^{(15)}$. In this perspective, we understand that the term adherence is associated with the social inclusion of individuals, the accessibility to dignified living conditions, and the organization of healthcare processes, a work that should not be restricted to meeting the biological and clinical needs, but also incorporate the social context ${ }^{(1)}$.

\section{Type of study}

This is a descriptive study of qualitative approach.

\section{Methodological procedures}

The study was composed by 14 Basic Health Units (UBS) located in three Technical Health Advisories (STS) in the municipality of São Paulo: Butantã, Campo Limpo, and Penha. They were selected for presenting, respectively, the highest cure rate $(81.8 \%)$, the lowest withdraw rate $(7.8 \%)$, and the highest withdraw rate $(21.3 \%)$ of the municipality ${ }^{(16)}$. Furthermore, due to the geographical extension of the municipality of São Paulo, we opted, for convenience, to select health units that were located in areas of easy access. The study subjects were nurses and physicians who cared for TB patients in Primary Health Care. We adopted as an inclusion criterion working in the health unit for over six months.

Eighty-six professionals were interviewed, based on a semi-structured instrument with open and closed questions. The testimonies analyzed here refer to 26 health professionals, since, from that number, there was repetition of information. As this is a qualitative research, it is understood that the sample represents a part of the whole in its varied aspects, being the interview a personal testimony that portrays the collectivity ${ }^{(17)}$. The interviews were conducted from May to July 2015.

The open-ended questions and qualitative approach that guided the interviews allowed the health professionals to speak freely about the theme: "tell us of a case in which you believe that the incentives offered to the patient with TB were significant for curing the disease" and "tell us of a case in which you believe that the incentives offered to the patient with TB were not significant for curing the disease".

The testimonies were recorded, transcribed in full, and analyzed by the speech analysis technique, based on the theory of generative meaning path (Greimas theory), which allows us to 
understand the empirical material from thematic phrases, which highlight meanings and categories ${ }^{(18-19)}$. The professionals were represented by letters of the alphabet and the thematic phrases by numbers (for example: A2). From these statements, four meanings emerged: living conditions of the people affected by TB; incentives as important for adherence to TB treatment; incentives as irrelevant to the adherence to TB treatment; and bond between the health team and the patient of TB versus adherence to treatment.

\section{RESULTS}

\section{Living conditions of people affected by Tuberculosis}

The association of TB to living and working conditions were present in the testimonies of the health professionals, who reported that people affected by the disease have, in general, "low income", "live poorly", "experience hunger", live in "precarious conditions", are "extremely vulnerable regarding their work", and use the social benefits for "providing for their family" (C11, C12, E2, H1, L1, M1, T8, U1, Z1).

It is said that the disease is prevalent in peripheral regions, where there are people who really need the incentives:

the case with greater seriousness we have are of people who live in a precarious situation. (T8)

It was stated that these patients usually are already registered in the Bolsa Família program and that often the offer of the incentive covers up the "real need that families today have in the neighborhood" (C10).

\section{Incentives as important for adherence to Tuberculosis treatment}

For the interviewed professionals, the incentives are fundamental to the adherence to TB treatment, particularly for patients with lower purchasing power and in situation of social vulnerability:

Bolsa Familia or any other incentive like that... helps improve the person's, the family's quality of life. (A1)

The more needy this patient is, really the basic food basket makes a very big difference, because it becomes a means of livelihood for this family. (V1)

Furthermore, the importance of the basic food basket was pointed out for the patient's "proper nutrition" during the treatment. Many patients, due to experiencing socioeconomic restrictions, "support their entire family with the basic food basket" (V1).

Although the offer of snacks is recommended by the Ministry of Health as an incentive to the treatment of TB, we only found in the regions of data collection the offer of basic food baskets and transportation stipends. However, health professionals who have experienced the period in which the municipality offered snacks to TB patients who attended the health unit for the DOT argued that adherence occurred due to this incentive. In addition to the caloric intake, offering a snack allowed for a moment of reunion and strengthened the bond between professionals and patients:

They drank coffee ... and it was a chance to talk about life. (C14)
It is important to clarify that snacks are currently offered only in some regions of São Paulo, because the health coordinations have autonomy in the decision of offering it or not.

\section{Incentives as irrelevant for adherence to Tuberculosis treatment}

Even though the social incentives are mostly considered relevant to the adherence to TB treatment, some professionals (7) remembered situations in which such measures may have had less impact, as in the case of patients considered "hard to control" (according to the health professionals themselves): underage patients whose mothers are "negligent" in the therapeutic accompaniment of TB; patients with a history of violence in the family; users of illicit drugs, alcoholics, or involved in drug trafficking; patients with stable economic situations; young adults; or patients who do not accept the illness. Other professionals also expressed that patients who understand the importance of the treatment do not depend on social incentives $(G 5, T 7, U 2)$.

Some professionals admit that social incentives can indirectly contribute to adherence to treatment, because the patients are afraid to lose them, as they are necessary for the maintenance of their lives:

It is more a matter of intimidation... it is not that it helps by itself... but rather for fear of losing the benefit. (A4)

We also found in one of the testimonies that, although incentives are offered, they do not eliminate the difficulties experienced by patients to obtain leaves from work due to the illness:

It is a little far from us... it is something very complicated... there is a lot of bureaucracy. (C16)

\section{Bond between the health team and the Tuberculosis patient versus adherence to treatment}

The testimonies highlighted the importance of the bond between health care professionals and TB patients for the achievement of adherence to treatment. The professionals considered that the "bond with the patient... is the basis, is essential" (A3) for the cure of the disease, as it allows "to tie up the treatment"(F1), especially in cases of vulnerable families. The importance of the bond built during DOT stood out, within the context of Family Health Strategy, because:

The bond, you delivering every day the medicine to him... and showing the importance of the treatment... is different from a once a month delivery... you end up not even knowing the patient from the area. (X3)

Going to the patient's home... meeting his family, [...] explaining to the family why it is tuberculosis, the importance of him following the treatment... meeting the family... son, daughter, other relatives involved... it ends up being a family network that helps in the treatment. (X4)

In cases of patients from other countries, the professionals pointed out the need for the health services to stablish a link with the leadership of the workplace where the sick people are employed, to ensure that employers understand the importance of treatment and facilitate the release of the worker for the DOT. 


\section{DISCUSSION}

This study contributes to the understanding of the importance of offering social incentives to TB treatment due to the social vulnerability to which patients are, in general, subjected. Although Brazil has a free TB treatment offered by the Unified Health System (SUS), evidence shows that patients present relevant health expenditure even if indirectly, such as the need to take a transportation to the health service (although one of SUS principles is regionalization) and food ${ }^{(20-21)}$. In the case of TB, it was assessed that this spending compromises from $8 \%$ to $20 \%$ of the patients' annual income ${ }^{(20)}$. Thus, social support - by the offer of food, transportation stipends, or monetary support - can mitigate the effects of the disease and assist in overcoming some of the barriers to treatment ${ }^{(22-23)}$.

The reversal of the TB epidemiological condition towards low incidence and mortality is due to the improvement of living and working conditions. Countries that have invested not only in social incentives for the treatment of TB, but especially in the establishment of a comprehensive protection system (for example, England, France, and Germany), have presented positive indicators in the control of the disease. Such countries have invested in ensuring rights through housing and income policies for the unemployed, pensions to reduce material deprivation in old age or in case of death of one of the spouses, among others ${ }^{(24-26)}$.

The analysis of the professional's speeches indicates that the incentives offered to TB patients are important for adherence to treatment. The literature shows that offering money and transportation stipends, among others, helps in the clinical improvement, especially for people who are in a more vulnerable situation, which corroborates the findings of this study ${ }^{(26-27)}$.

Regarding food incentives, studies show that it acts positively on adherence to treatment of TB, with reduction of mortality rates and treatment failures ${ }^{(27-29)}$. In this research, the interviewed professionals stressed the importance of the basic food basket, which benefitted not only the patients, but also the livelihood of their families, due to their general living condition.

As well as the basic food basket, the transportation stipend was also pointed out as potential facilitator of adherence to treatment. Compliance with the DOT recommendations for all patients require their attendance to the health unit daily, from Monday to Friday. For operational purposes, are considered as undergoing DOT the patients who had 24 supervised doses in the first phase of treatment and 48 supervised doses in the second phase. This frequency can result in significant expense, as they mean necessary displacements to the health unit ${ }^{(9)}$. Indeed, studies show a higher risk of non-adherence to treatment among patients with economic constraints due to transportation $\operatorname{costs}^{(22,30)}$.

It is important to note that, in São Paulo, all Health Coordinations offer basic food basket and transportation stipends to patients who are undergoing DOT. However, there is no legislation that officiate as obligatory the offering of basic food basket for TB patients in this treatment modality ${ }^{(31)}$.

Concerning the offer of snacks to patients in DOT, some professionals pointed out its importance to guarantee the strategy and regretted its restriction in the municipality. At the time the study was carried out, this occurred only in the region under the responsibility of the East Health Coordination.
On the other hand, some professionals expressed that incentives do not influence the adherence of specific groups, such as users of illicit drugs, alcoholics, people who live on the streets, among others. This conception is based on the understanding that such groups are inserted into specific contexts of vulnerability, which interfere with following the therapy: in general, individuals from these groups do not have a routine, lack family support or other people, have reduced self-esteem, and do not possess the minimum conditions for a life with dignity. Furthermore, the use of illicit drugs and alcohol can cause behavioral changes that enhance rejection to the medication ${ }^{(32-34)}$. However, it is also necessary to consider that the interpretation that incentives do not influence the adherence of these specific groups is full of stereotypes, which are often used as a reason for not monitoring patients in these situations.

Specifically concerning people who live on the streets, studies show that incentives for transportation and food are relevant to increase adherence to treatment ${ }^{(23,28)}$. It is also important to consider that the positioning of certain professionals, regarding the neutral effect of offering basic food baskets to patients living on the streets, may be due to the fact that certain foods that are part of the basic basket require cooking, which can be impractical in this condition.

Still concerning this group of patients, which are in such contexts of vulnerabilities, we verified in this study that the trust relationship between the health professional and the patient and the necessary autonomy of the latter regarding shared decisions during the treatment can improve the acceptance of the diagnosis and promote adherence to treatment ${ }^{(35)}$.

The bond constructed between the health team and the patient during the DOT allows understanding the social and family context of TB patients and reduce treatment withdraw ${ }^{(36-38)}$. The bond provides the understanding of patients' needs, in addition to promoting a feeling of appreciation, reception, and social inclu$\operatorname{sion}^{(1)}$. Although only nurses and physicians were interviewed, the bond must be established between all professionals involved in the treatment, highlighting the fundamental participation of the nurse as the person responsible for the supervision of the $\mathrm{DOT}^{(39-41)}$.

This study contributed to show one facet of the Brazilian reality regarding the influence of incentives on adherence to treatment of TB patients, from the perspective of health professionals. However, it is necessary to remember that this topic is subsumed, i.e., it is part of a broader understanding, which refers to the understanding that inadequate living conditions, health services, criminal service - in addition to migratory movements, seeking refuge, among others - hinder the control of the disease and may induce the patient to withdraw from the treatment ${ }^{(42-43)}$. Therefore, specific incentives are not enough when the goal is to eliminate TB.

\section{Study limitations}

A possible limiting element of this study refers to the number of professionals who mentioned more comprehensive social protection measures, such as the Bolsa Família program and the Continued Provision benefit, and their influence on adherence to TB treatment and on the Disease Control Program. However, the scarcity of reports of this nature did not prevent the analysis of the perception of these professionals about the importance of social incentives for strengthening adherence to TB treatment. 


\section{Contributions to the field of nursing}

Social incentives, such as basic food basket and the transportation stipends, are recommended by the National Tuberculosis Control Program. Such incentives increase TB treatment and act as facilitators of adherence, mainly because most of the individuals affected by the disease present significant weaknesses in their living and working conditions. This condition is relevant to health professionals, in particular the nursing staff, which work actively in the treatment and control of the disease. In this way, it is essential that nurses have information about the social incentives to guide patients concerning their rights. We reiterate the need for nursing professionals to act raising awareness of the determinants that lead to TB, in order to reduce social inequalities.

\section{FINAL CONSIDERATIONS}

Incentives (basic foo basket and transportation stipends) are accepted as important and generally favor adherence, especially in the case of patients in situations of extreme social vulnerability. The provision of such incentives along with the Directly Observed Treatment and the bond established between the professional and the TB patient strengthen adherence to treatment.

However, assuming that TB is the result of social inequalities, such incentives only minimize the situation of suffering of the people affected by the disease. Therefore, social protection must constitute the structure of society, which has shown to be effective in some countries, and not just artifices to mitigate poverty. Thus, actions that integrate policies aimed at overcoming inequalities are fundamental for the achievement of a more equitable society and, therefore, to control this disease.

\section{FUNDING}

National Council for Scientific and Technological Development (CNPq), process no. 134346/2014-9.

\section{REFERENCES}

1. Bertolozzi MR. A adesão ao tratamento da tuberculose na perspectiva da estratégia do tratamento diretamente supervisionado (DOTS) no município de São Paulo [Tese]. Universidade de São Paulo, Escola de Enfermagem; 2005.

2. Belo MTCT, Selig L, Luiz RR, Hanson C, Luna AL, Teixeira EG, et al. Choosing incentives to stimulate tuberculosis treatment compliance in a poor country in Rio de Janeiro state, Brazil. Med Sci Monit [Internet]. 2006 [cited 2017 Jul 30];12(5):PH1-5. Available from: https://www. medscimonit.com/download/index/idArt/450296

3. Pinto PFPS, Silveira C, Rujula MJP, Chiaravalloti F Neto, Ribeiro MCSA. Epidemiological profile of tuberculosis in São Paulo municipality from 2006 to 2013. Rev Bras Epidemol [Internet]. 2017 [cited 2018 Feb 7];20(3):549-57. Available from: http://www.scielo.br/pdf/rbepid/v20n3/ en_1980-5497-rbepid-20-03-549.pdf

4. World Health Organization. Global tuberculosis report 2016 [Internet]. Geneva (CH): Author; 2016 [cited 2017 Jul 30]. Available from: http:// www.who.int/tb/publications/global_report/gtbr2016_executive_summary.pdf

5. Munõz Sanchez Al, Bertolozzi MR. Beyond DOTS (Directly Observed Treatment Short-Course) in tuberculosis' control: interfacing and sharing needs. Rev Latino-Am Enfermagem [Internet]. 2009 [cited 2017 Jul 30];17(5):689-94. Available from: http://www.scielo.br/pdf/rlae/ v17n5/15.pdf

6. Orr P. Adherence to tuberculosis care in Canadian Aboriginal populations part 2: a comprehensive approach to fostering adherence behavior. Int J Circ Health. 2011 [;70(2):128-40: https://www.tandfonline.com/doi/pdf/10.3402/ijch.v70i2.17810

7. World Health Organization. Global tuberculosis report 2013 [Internet]. Geneva (CH): Author; 2013 [cited 2017 Jul 30]. Available from: http:// apps.who.int/iris/bitstream/10665/91355/1/9789241564656_eng.pdf

8. Terra MF, Bertolozzi MR. Does Directly Observed Treatment ("DOTS") contribute to tuberculosis treatment compliance? Rev Latino-Am Enfermagem [Internet]. 2008 [cited 2017 Jul 30];16(4):659-64. Available from: http://www.scielo.br/pdf/rlae/v16n4/02.pdf

9. Ministério da Saúde (BR). Manual de recomendações para o controle da tuberculose no Brasil [Internet]. Brasília (DF): 2011 [cited 2017 Jul 30]. Available from: http://bvsms.saude.gov.br/bvs/publicacoes/manual_recomendacoes_controle_tuberculose_brasil.pdf

10. Torrens AW, Rosella D, Boccia D, Maciel ELN, Nery JS, Olson ZD, et al. Effectiveness of a conditional cash transfer programme on TB cure rate: a retrospective cohort study in Brazil. Trans R Soc Trop Med Hyg [Internet]. 2016 [cited 2017 Dec 19];110(3):199-206. Available from: https:// www.ncbi.nlm.nih.gov/pmc/articles/PMC6078175/pdf/emss-78230.pdf

11. Ministério do Desenvolvimento Social e Combate à Fome (BR). Organização das Nações Unidas para a Educação, a Ciência e a Cultura. Concepção e gestão da proteção social não contributiva no Brasil [Internet]. Brasília (DF): 2009 [cited 2017 Mar 24]. Available from: http:// www.mds.gov.br/webarquivos/publicacao/assistencia_social/Livros/concepcao_gestao_protecaosocial.pdf

12. Pinheiro RS, Oliveira GP, Oliveira EXG, Melo ECP, Coeli CM, Carvalho MS. [Social determinants and self-reported tuberculosis: National Research by Household Sample, metropolitan areas, Brazil]. Rev Panam Salud Publica [Internet]. 2013 [cited 2017 Mar 24];34(6):44651. Available from: https://www.scielosp.org/article/ssm/content/raw/?resource_ssm_path=/media/assets/rpsp/v34n6/v34n6a11.pdf Portuguese.

13. World Health Organization. Global tuberculosis report 2017 [Internet]. Geneva (CH): Author; 2017 [cited 2017 Jul 30]. Available from: http:// apps.who.int/iris/bitstream/10665/259366/1/9789241565516-eng.pdf

14. Breilh J. [The social health determination as a tool of transformation towards a new public health (community health)]. Rev Fac Nac Salud Pública 
[Internet]. 2013 [cited 2017 Feb 24];31(Suppl 1):S13-S27. Available from: http://www.scielo.org.co/pdf/rfnsp/v31s1/v31s1a02.pdf Spanish.

15. Fonseca RMGS, Egry EY, Bertolozzi MR. O materialismo histórico e dialético como teoria da cognição e método para a compreensão do processo saúde-doença [Internet]. In: Egry EY, Cubas MR, editors. O trabalho da enfermagem em saúde coletiva no cenário CIPESC. Curitiba (PR): Associação Brasileira de Enfermagem; 2006. p. 19-61.

16. Prefeitura de São Paulo (BR). Boletim TB 2009: Programa de Controle da Tuberculose. São Paulo (SP): Author; 2009.

17. Minayo MCS. O desafio do conhecimento: pesquisa qualitativa em saúde. 14th ed. São Paulo (SP): Hucitec; 2014.

18. Fiorin JL. Elementos de análise do discurso. São Paulo (SP): Contexto; 2016.

19. Car MR, Bertolozzi MR. O procedimento da análise de discurso. In: Chianca TCM, Antunes MJM, editors. A classificação internacional das práticas de enfermagem em saúde coletiva: CIPESC. Brasília (DF): Associação Brasileira de Enfermagem; 1999. p. 348-355.

20. Xu K, Evans DB, Kawabata K, Zeramdini R, Klavus J, Murray CJL. Household catastrophic health expenditure: a multicountry analysis. Lancet [Internet]. 2003 [cited 2017 Jul 30];362(9378):111-7. Available from: http://www.who.int/health_financing/documents/lancet-catastrophic_ expenditure.pdf

21. Boing AC, Bertoldi AD, Barros AJD, Posenato LG, Peres KG. Socioeconomic inequality in catastrophic health expenditure in Brazil. Rev Saúde Pública [Internet]. 2014 [cited 2017 Jul 30];48(4):632-41. Available from: http://www.scielo.br/pdf/rsp/v48n4/0034-8910-rsp-48-4-0632.pdf

22. Grede N, Claros JM, Pee S, Bloem M. Is there a need to mitigate the social and financial consequences of tuberculosis at the individual and household level? AIDS Behav [Internet]. 2014 [cited 2017 Jun 6];18(Suppl 5):S542-S553. Available from: https://link.springer.com/content/ pdf/10.1007\%2Fs10461-014-0732-0.pdf

23. Lutge EE, Wiysonge CS, Knight SE, Sinclair D, Volmink J. Incentives and enablers to improve adherence in tuberculosis. Cochrane Database Syst Rev.;2015(9): CD007952.: https://www.cochranelibrary.com/cdsr/doi/10.1002/14651858.CD007952.pub3/epdf/full

24. Lönnroth K, Glaziou P, Weil D, Floyd K, Uplekar M, Raviglione M. Beyond UHC: monitoring health and social protection coverage in the context of tuberculosis care and prevention. PLoS Med [Internet]. 2014 [cited 2017 Jun 6];11(9):e1001693. Available from: https://journals. plos.org/plosmedicine/article/file?id=10.1371/journal.pmed.1001693\&type=printable

25. Lönnroth K, Castro KG, Chakaya JM, Chauhan LS, Floyd K, Glaziou P, et al. Tuberculosis control and elimination 2010-50: cure, care, and social development. Lancet [Internet]. 2010 [cited 2017 Jun 6];375(9728):1814-29. Available from: http://ses.sp.bvs.br/local/File/Tuberculosis\%20 control\%20and\%20elimination\%202010-50_cure,\%20care,\%20and\%20social\%20development.pdf

26. Reeves A, Basu S, McKee M, Stuckler D, Sandgren A, Semenza J. Social protection and tuberculosis control in 21 European countries, 19952012: a cross-national statistical modelling analysis. Lancet Infect Dis [Internet]. 2014 [cited 2017 Jun 9];14(11):1105-12. Available from: https://www.thelancet.com/journals/laninf/article/PIIS1473-3099(14)70927-2/fulltext

27. Mookherji S, Beith A. Summary of current evidence: using incentives and enablers for improved DOTS performance [Internet].; 2006 [cited 2017 Jun 6]. Available from: https://www.researchgate.net/profile/Sangeeta_Mookherji/publication/238676483_Summary_of_Current_ Evidence/links/004635329bf6920443000000/Summary-of-Current-Evidence.pdf

28. Gärden B, Samarina A, Stavchanskaya I, Alsterlund R, Övregaard A, Taganova O, et al. Food incentives improve adherence to tuberculosis drug treatment among homeless patients in Russia. Scand J Caring Sci [Internet]. 2013 [cited 2017 Jun 9];27(1):117-22. Available from: http://onlinelibrary.wiley.com/doi/epdf/10.1111/j.1471-6712.2012.01009.x

29. Chua APG, Lim LKY, Ng H, Chee CBE, Wang YT. Outcome of a grocery voucher incentive scheme for low-income tuberculosis patients on directly observed therapy in Singapore. Singapore Med J [Internet]. 2015 [cited 2017 Jun 9];56(5):274-9. Available from: http://www.smj.org. sg/sites/default/files/SMJ-56-274.pdf

30. Herrero MB, Ramos S, Arrossi S. Determinants of non adherence to tuberculosis treatment in Argentina: barriers related to access to treatment. Rev Bras Epidemiol [Internet]. 2015 [cited 2017 Jun 16];18(2):287-98. Available from: http://www.scielo.br/pdf/rbepid/ v18n2/1415-790X-rbepid-18-02-00287.pdf

31. Organização Pan-Americana de Saúde. Direitos humanos, cidadania e tuberculose na perspectiva da legislação brasileira [Internet]. 2015 [cited $2017 \mathrm{Jul}$ 30]. Available from: https://www.paho.org/bra/index.php?option=com_docman\&view=download\&alias=1514-direitoshumanos-cidadania-e-tuberculose-na-perspectiva-da-legislacao-brasileira-4\&category_slug=tuberculose-971\&ltemid=965

32. Burki T. Tackling tuberculosis in London's homeless population. Lancet [Internet]. 2010 [cited 2017 Jun 16];376(9768):2055-6. Available from: http://www.thelancet.com/pdfs/journals/lancet/PIIS0140-6736(10)62282-9.pdf

33. Couto DS, Carvalho RN, Azevedo EB, Moraes MN, Pinheiro PGOD, Faustino EB. [Determinant factors for tuberculosis treatment dropout: representations of patients at a public hospital]. Saúde Debate [Internet]. 2014 [cited 2017 Jun 16];38(102):572-81. Available from: http:// www.scielo.br/pdf/sdeb/v38n102/0103-1104-sdeb-38-102-0572.pdf Portuguese.

34. Lackey B, Seas C, Van der Stuyft P, Otero L. Patient characteristics associated with tuberculosis treatment default: a cohort study in a high-incidence area of Lima, Peru. PLoS One [Internet]. 2015 [cited 2017 Jun 16];10(6):e0128541. Available from: https://journals.plos.org/ plosone/article/file?id=10.1371/journal.pone.0128541\&type=printable

35. De Vries SG, Cremers AL, Heuvelings CC, Greve PF, Visser BJ, Bélard S, et al. Barriers and facilitators to the uptake of tuberculosis diagnostic and treatment services by hard-to-reach populations in countries of low and medium tuberculosis incidence: a systematic review of qualitative literature. Lancet Infect Dis [Internet]. 2017 [cited 2017 Dec 19];17(5):e128-e143. Available from: https://www.thelancet.com/ journals/laninf/article/PIIS1473-3099(16)30531-X/abstract 
36. Sá LD, Gomes ALC, Nogueira JA, Villa TCS, Souza KMJ, Palha PF. Intersectorality and bonding in tuberculosis control in family health. Rev Latino-Am Enfermagem [Internet]. 2011 [cited 2017 Jun 16];19(2):387-95. Available from: http://www.scielo.br/pdf/rlae/v19n2/22.pdf

37. Queiroz EM, De-La-Torre-Ugarte-Guanilo MC, Ferreira KR, Bertolozzi MR. Tuberculosis: limitations and strengths of Directly Observed Treatment Short-Course. Rev Latino-Am Enfermagem [Internet]. 2012 [cited 2017 Jun 19];20(2):369-77. Available from: http://www.scielo. $\mathrm{br} / \mathrm{pdf} / \mathrm{rlae} / \mathrm{v} 20 \mathrm{n} 2 / 21 . \mathrm{pdf}$

38. Souza KMJ, Sá LD, Silva LMC, Palha PF. Nursing performance in the policy transfer of directly observed treatment of tuberculosis. Rev Esc Enferm USP [Internet]. 2014 [cited 2017 Jun 19];48(5):870-8. Available from: http://www.scielo.br/pdf/reeusp/v48n5/0080-6234reeusp-48-05-874.pdf

39. Rêgo CCD, Macêdo SM, Andrade CRB, Maia VF, Pinto JTJM, Pinto ESG. [Nurse working process of people with tuberculosis in primary health care]. Rev Baiana Enferm [Internet]. 2015 [cited 2017 Jun 19];29(3):218-28. Available from: https://portalseer.ufba.br/index.php/ enfermagem/article/download/13038/pdf_5 Portuguese.

40. Hino P, Takahashi RF, Bertolozzi MR, Egry EY. The health needs and vulnerabilities of tuberculosis patients according to the accessibility, attachment and adherence dimensions. Rev Esc Enferm USP [Internet]. 2011 [cited 2017 Jun 19];45(Suppl 2):1656-60. Available from: http:// www.scielo.br/pdf/reeusp/v45nspe2/en_03.pdf

41. Queiroz EM, Bertolozzi MR. Tuberculosis: supervised treatment in North, West and East Health departments of São Paulo. Rev Esc Enferm USP [Internet]. 2010 [cited 2017 Jun 6];44(2):449-56. Available from: http://www.scielo.br/pdf/reeusp/v44n2/en_30.pdf

42. Rodrigues ILA, Monteiro LL, Pacheco RHB, Silva SED. Abandonment of tuberculosis treatment among patinets co-infected with TB/HIV. Rev Esc Enferm USP [Internet]. 2010 [cited 2017 Jun 6];44(2):380-4. Available from: http://www.scielo.br/pdf/reeusp/v44n2/en_20.pdf

43. Santos LAR, Fukasava S, Galesi VMN. Alguns aspectos epidemiológicos do controle da tuberculose no estado de São Paulo. BE CVE [Internet]. 2012 [cited 2016 Jun 9];2(11):178-88. Available from: http://portal.saude.sp.gov.br/resources/cve-centro-de-vigilanciaepidemiologica/publicacoes/e-becve/bol1112.pdf 